\title{
Louisiana College: Factors in the Initial Survival of a Later Denominational College
}

\author{
Joseph Learned Odenwald*
}

* President of Southwestern Michigan College, Dowagiac, MI, Cass County, United States

Email: jodenwald@swmich.edu

\section{Article Info}

Received: January 11, 2022

Revised: February 7, 2022

Accepted: February 12, 2022

\section{$10.46303 /$ jcsr. 2022.5}

\section{How to cite}

Odenwald, J. L. (2022). Louisiana College: Factors in the Initial Survival of a Later Denominational College. Journal of Curriculum Studies Research, 4(1), 43-57

https://doi.org/10.46303/jcsr.2022.5

\section{Copyright license}

This is an Open Access article distributed under the terms of the Creative Commons Attribution 4.0 International license.

https://creativecommons.org/licenses/by/4.0/

\section{ABSTRACT}

The following historical case study considers the initial history of Louisiana College. It utilizes primary and secondary sources, including dissertations, local histories, news articles, speeches, catalogs, yearbooks, and financial statements. The methods employed were historical, but the framework was that of an educationist. Beyond merely telling the story of the initial years of Louisiana College, the goal was to understand what contributed to the college's perpetuity in light of the mortality of similar institutions. As we face a period of a demography unfavorable to our system of colleges and universities, it is imperative that leaders and the broader stakeholders of particular institutions have a grasp of the factors that lead to institutional health and decline.

\section{KEYWORDS}

Louisiana College; Baptists; Baptist education; Denominational Colleges; religious education; higher education history. 


\section{INTRODUCTION}

Louisiana College, located in Pineville, shares a heritage, though it was initiated later than most others, with what scholars call the antebellum, old-time, or denominational colleges. These church-related institutions were largely opened between 1830 and 1860, and were a direct result of the Second Great Awakening (Ringenberg 2006). Religious zeal, combined with a newfound openness to higher education, led many Baptist, Methodist, and Presbyterian ministers to found the more than 200 such colleges that emerged during the period. John Thelin (2019) suggests that higher education was America's cottage industry between 1785 and 1860 . And the reasons were not exclusively religious. Towns were eager to land a college, and ministers would offer the highest bidding locale the right to call itself a "college town" (Ringenberg 2006). There were economic and cultural benefits to being the home of an institution. The success and failure of these American institutions were usually tied to the size of their host community, its proximity to transportation (in this era, rail), the ability to attract a committed and often long-suffering faculty and staff, whether or not a thriving student life would emerge, the stability of its leadership, and if it could attract local or more broad financial support. In the case of Louisiana College, two previous Baptist institutions and their failures gave birth to the notion of a more centrally-located college (Pineville is located approximately twenty-five miles from the geographic center of the state), and its survival during its first two decades was a direct result of having found favor with the aforementioned.

\section{Beginnings of Baptist Higher Education in Louisiana}

The historian Landrum Salley $(1985,65)$ summarizes well the issues that plagued the two original Baptist colleges in Louisiana. "These some-what typical $19^{\text {th }}$ century colleges-small, provincial, isolated-could not survive the accelerated pace of the $20^{\text {th }}$ century." Landrum also called them "the spiritual predecessors" of Louisiana College, thus it is important to consider them before discussing the first two decades of Louisiana College's history. Baptists, led by Martin Canfield of South Carolina, brought the faith with them to remote Northern Louisiana in the late 1830s:

Unlike the stereotype of the pioneer in an isolated cabin, some of these new arrivals in north Louisiana lost no time in recreating the cultural patterns and community life they had left behind but not rejected. Churches and schools appeared soon after the clearing of the fields for cultivation, and within a decade or so after settlement, these hardy souls had built towns that, despite their distance from centers of trade and arteries of commerce, bore many of the marks of a village in Virginia or South Carolina with 100 years of history behind it (Salley 1985, 51).

President Lyndon Baines Johnson's great-grandfather, George W. Baines, pastored what became known as the Mount Lebanon Baptist Church. The church spawned the North Louisiana Baptist Convention (later Louisiana Baptist Convention) in 1848 and Mount Lebanon University in 1852 (Salley 1985). 
Mount Lebanon University, located in Mount Lebanon, was really a preparatory school in its earliest years, offering college courses for the first time in 1856. It later took the name "Mount Lebanon College." Women were admitted in 1859, but took their courses on another campus (Salley 1985). The Civil War, as it did so many institutions, affected Mt. Lebanon University. It closed in 1863, and shortly after the war the buildings burned, leaving the institution without a physical plant. Worse, the Convention dropped its support in the mid1870s (Salley 1985). The college's enrollment saw a brief rebound in the 1880 s, thanks in part to generous lenders. Electric lights and steam heat, combined with a broad curriculum it could not ultimately deliver, boosted enrollment to nearly 350 in 1888-1889. But debts forced the selling of the lights and heating system, and during the 1890s the college saw sharp enrollment declines of what was a largely preparatory student body (Salley 1985). It closed its college division at the end of the 1905-1906 session.

Keatchie Female College, located in Keatchie, funded by the Grand Cane Baptist association, an affiliate of the Louisiana Baptist Convention, opened in 1856 (Salley 1985). It was arguably the weaker of the two institutions, never seeing enrollment top 100. It began admitting men in 1887, changing its name to "Keatchie Male and Female College, but a decade later changed its name again to "Louisiana Female College," only admitting men who could live at home. Throughout the first years of the twentieth century, the college would close for a year and then re-open. This was obviously devastating to the enrollment, and it closed for good in 1912 (Salley 1985). In the end, its rural and sparsely populated location and insistence, like Mount Lebanon, on offering a broad curriculum largely doomed the college.

\section{Desire for a Centrally Located Baptist College}

Previous historians (May 1956, Brister 1968, and Greene 1973) have observed that the origins of Louisiana College can be traced to a resolution made by Edwin O. (E. O.) Ware, Secretary for the Louisiana Baptist Convention, at a meeting of the convention in 1893:

Whereas the Baptists of the State of Louisiana have no school or college in any true sense their own and Whereas. It seems evident that the State has begun an era of development unparalleled in the past and Whereas. It is always the part of wisdom to prepare for the future though HE may not live IN that future, therefore BE IT RESOLVED. That the President of this Convention be and is hereby instructed to appoint a special committee of fifteen brethren representing the different parts of the State whose duty it shall be to canvass the educational situation among the Baptists of the State and at the next (1894) session of the Convention, make [a] report as to the advisability and feasibility of establishing a College which shall have organic connection with this Convention (Higgins 1971, 24).

Ware's resolution, though not successful, led to many special committees and conversations over the next several years as how to proceed with Baptist higher education in Louisiana (Higgins 1971). In 1904, the Education Commission, comprised of thirteen individuals, 
was appointed by the Convention to a secure a location for a new and centrally-located college (Higgins 1971). At this time, much of north Louisiana was rural, and the concept of a centrallylocated college meant one that could be easily reached by various rail lines. Ultimately after a ten-hour session on January 19, 1906, Pineville (population 617 in 1900), a small village, located on the opposite side of the Red River, was chosen by a vote of 10-5 over the larger City of Alexandria (population 5,648 in 1900), which had offered $\$ 30,000$ for the establishment of the college ("The State Baptist College to be Located Back of Pineville" 1906). The reason for the choice of Pineville over Alexandria was a desire for substantial acreage. Despite E. O. Ware and others offering to give of their own land on the Alexandria side of the Red River, the total did not equal thirty acres needed for the campus. A. Albert of Pineville donated forty wooded acres for the establishment of the college. The funds raised by the citizens of Alexandria were accepted by the Commission ("The State Baptist College to be Located Back of Pineville 1906).

Ware, who first planted the seeds for Louisiana College in 1893, and who offered of his own land for the location of the college, was appointed financial agent for the Commission. With the college having no true administrative structure, Ware oversaw most of details that occupy the time of a college president and their administration ("Commission of State Baptist College Met Here Last Night" 1906). This part-time role, perhaps because it became so time consuming, was expanded into a full-time one by mid-summer. A subset of the Commission, comprised (depending on the year) of five to eight persons, mostly living near the college, served as the board of directors (Higgins 1971).

\section{Selecting a Name and the First Faculty}

The Commission considered as many as fourteen names for the new college, among them Louisiana Baptist College, Red River College, The E. O. Ware Central Baptist College, Louisiana College, The Louisiana Central Baptist College, and Alexandria College (Higgins 1971). Much debate occurred over the potential inclusion of the word "Baptist," and some were concerned that local names, perhaps like Mount Lebanon and Keatchie, might be deemed too provincial. Louisiana College was chosen, though not all were satisfied. Future faculty member Bruce Benton commented, "We had hoped the college would have a different name, but now...we are satisfied" (Higgins 1971, 69).

After Pineville was selected as the site for Louisiana College, Ware and the board of directors were faced with the next challenges of attracting a faculty, recruiting students, and establishing a physical plant. The faculty were hired before the end of the spring. Sealed bids for construction of the dormitory and mess hall were sought in May ("Notice, Contractors" 1906). Ground was broken on June 11, 1906, by J.D. Bragg ("Ground Broken for Baptist College" 1906). Recruiting of male students was done primarily by faculty members sending letters to the Baptist churches in the state, asking for lists of potential students to whom materials about the college could be sent. More than 300 such requests were mailed to the churches ("The Louisiana College" 1906). 


\section{The College Opens to Any Male}

Louisiana College officially opened on October 2, 1906, with nineteen students, some of whom who transferred from Mount Lebanon College, and three faculty members (see photo below). The inaugural faculty included F. E. Taylor, previously the president of the Ruston Industrial Institute, a news editor Bruce Benton, and Claybrook Cottingham, previously the president of Mt. Lebanon College. Classes began in a single wooden structure the same day the foundation was poured for the first permanent structure ("Louisiana Baptist College Opened for Session" 1906).

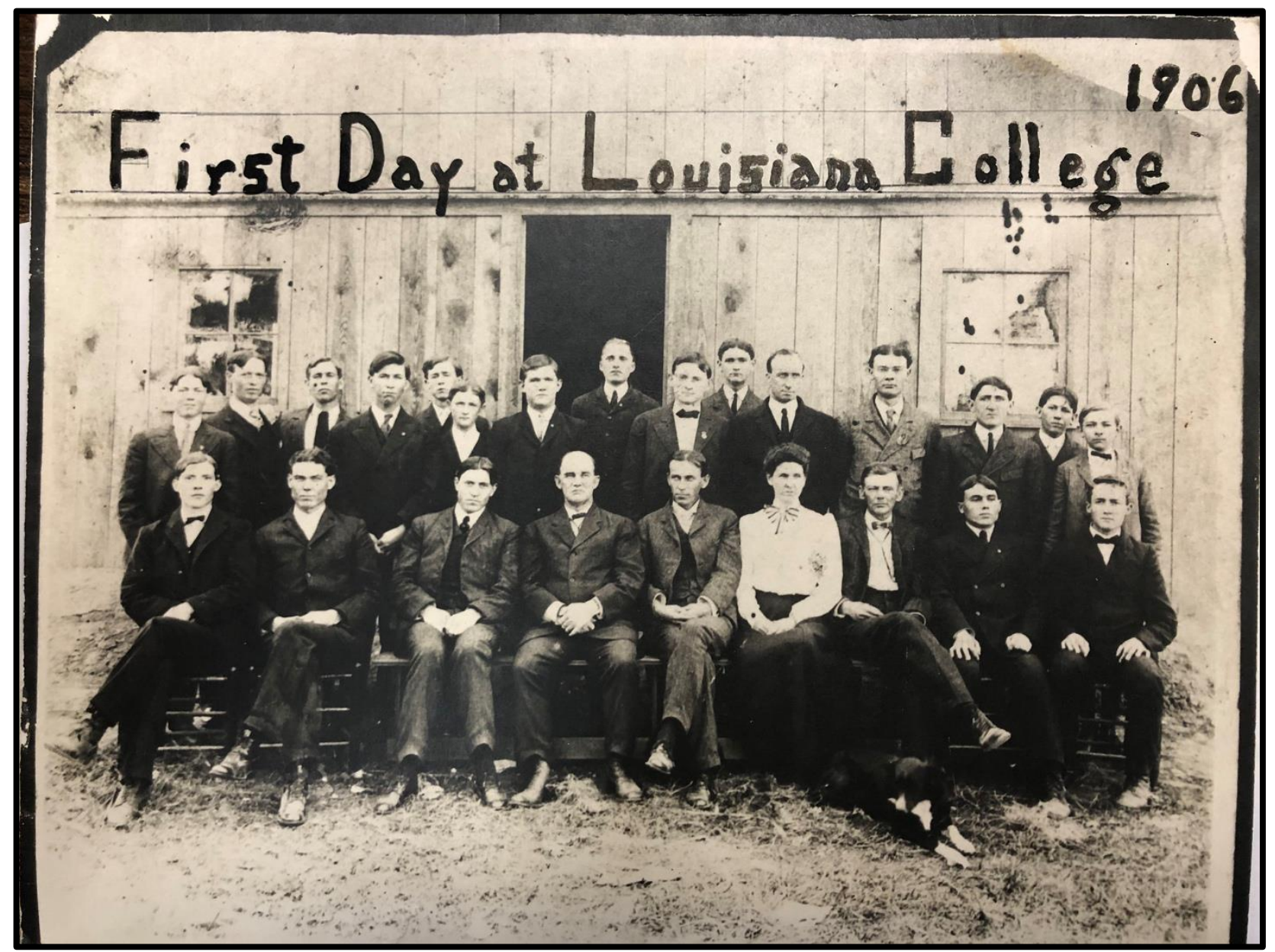

Image 1. "Louisiana College's first building," c. 1906. Image courtesy of the Richard W. Norton Library, Archives, Pineville, Louisiana.

Despite its Baptist affiliation, Louisiana College was open to "any man seeking a college education." Among its purposes, the earliest catalog available lists moral development, character building, training laymen for business, and educating the clergy (Catalog of Louisiana College, 1908-1909). The next catalog was more explicit and ambitious in its aim to count lawyers, engineers, farmers, doctors, merchants, judges, and even governors among its alumni. It further specified that the college's sole purpose was not the training of ministers, "Louisiana 
College is owned and controlled by the Baptists of the State, but it is not a Theological School" (Catalog of Louisiana College, 1909-1910).

The college, not unlike public and other private institutions of the era, whether religious or not, maintained strict behavioral regulations. Gambling, cursing, and weapons were not permitted on campus. Initially, students residing on campus were not permitted to leave the premises without permission (Catalog of Louisiana College, 1908-1909). By 1910, this was relaxed and students were allowed to leave campus between three-thirty and five-thirty on weekday afternoons, and, of course, for Sunday church services. Students residing off campus were required to have their living arrangements pre-approved by the faculty (Catalog of Louisiana College, 1910-1911). Most students made their way to Pineville by way of train, and a "college wagon," drawn by horses, transported luggage to the campus on move-in days. In addition to regulations, the college boasted in its early years of a "deeply religious culture," as faculty led the students in a daily and mandatory chapel program (Catalog of Louisiana College, 1908-1909).

The earliest students were primarily from the State of Louisiana and from parishes in central Louisiana; students' names and home towns were listed in the catalogs. For the second session, two students were from out of state, one from Texas and one from Mississippi. One international student from Brazil appeared on the roll (Catalog of Louisiana College, 1908-1909). The first two graduates of Louisiana College, who had begun their education at Mt. Lebanon College, Thomas Justin Moore and James Lee Raley, earned their degrees in 1907 (Catalog of Louisiana College, 1910-1911). Moore would later earn a law degree from Harvard, become an attorney in Richmond, Virginia, and serve as a trustee for the University of Richmond. Raley would attend Brown, and serve on the faculty at Mississippi College, Mercer University, and for his alma mater (Cottingham 1947).

\section{Early Challenges}

Once it opened, Louisiana College faced steep competition from other developing colleges in Louisiana amid a challenging economy. The boll weevil wreaked havoc on the state's cotton economy in the earliest years of operation, and enrollment dropped from seventy-five to forty between 1907 and 1908 (Salley 1985). This may have led to the appointment of E. O. Ware in that year, replacing F.E. Taylor who had served as chair of faculty in addition to teaching. For the 1908-1909 session, tuition was set at five dollars per month or twenty dollars per half session. Room and board were fifty-nine dollars per half session. Ministerial students received a fifty-percent reduction in their tuition. This was likely a strategy to demonstrate to the Convention that the college was doing its part in training ministers (Higgins 1971).

By 1908, the college had expanded its physical plant. The original building, also called "Old Main" or "Ware Hall" housed offices, classrooms, and dormitory rooms for about onehundred. A brick "mess hall" housed the kitchen and space for communal meals. The original wooden structure, erected and used during the first session, served as an assembly hall. The 
college largely relied upon a Carnegie Library in Alexandria to serve students and faculty, but a campaign for a library collection was well under way in the third session (Higgins 1971).

It was not uncommon in the 1910s for Louisiana College faculty and staff to receive less than their full salary. The 1910 financial statement reveals that of the college's $\$ 40,028.66$ in liabilities, \$4,350.66 was owed to current or former faculty, staff, and administration ("Statement of Louisiana College" 1910). Total assets, including the building, endowment, furniture and fixtures, wells and engines, livestock and wagon, the campus, and pledges was just $\$ 86,842.75$. Less total liabilities, Louisiana College was valued at less than $\$ 50,000.00$. One of the college's major problems in its earliest years and even through the Great Depression was its reliance upon subscriptions or pledges. Often, the annual budget was built upon promissory notes of faithful Baptist laity throughout the state. While these were people of good intentions, their own hardships often made meeting their subscriptions or pledges to the college impossible. This led to budgets ending in the red and the liabilities owed to businesses and employees.

\section{The Earliest Curriculum and Campus Life}

Because we do not have the catalogs from the first two years of the college's existence we can best conclude that general education courses were offered. The first catalog of record, 19081909, notes that English was required all four years (Catalog of Louisiana College, 1908-1909). Special courses were offered in stenography, bookkeeping, and music. A wide range of courses were offered in the arts and sciences. The following year, the college was organized into nine schools, essentially departments, including Latin, Greek, mathematics, science, history, philosophy and economics, modern languages, Bible, and music (Salley 1985). The demand for public school teachers in Louisiana and the subsequent impact on enrollment led to a 1910 effort to improve pedagogy courses, so that graduates could receive licensure with only a subject-specific examination. By 1913, this arrangement appeared in the catalog. Graduates needed only to pass an exam in the theory and art of teaching (Catalog of Louisiana College, 1913-1914).

A campus life emerged in the earliest years with the development of two literary societies, the Cadmians and Athenians, providing intellectual and physical competitions. Every student was encouraged to be a member of one group or the other. A ministerial association, sometimes referred to as a theological society, provided for Bible study opportunities and support for students preparing for a career in the clergy (Higgins 1971).

\section{Leadership Turnover and Stability}

Ware served a single year as president, and William Christopher (W. C.) Friley was selected as president in 1909. Friley came to the college with a sterling record, having served as the founding president of Simmons College in Texas and of Ruston College, a forerunner of the Louisiana Industrial Institute, located in Ruston. He only agreed to serve upon the condition that the college would become co-educational. The admission of women in 1909 increased 
enrollment, but led to criticism that this strategy hurt the enrollment of Louisiana Female College. The inclusion of women did not dramatically improve the college's overall enrollment. The co-educational strategy was publicly criticized in the Convention's annual meeting:

It is proper to submit in this place that there are members of the Board who do not prefer co-education, and their agreement to its adoption was yielded because it was declared to be a necessary measure in view of the peculiar emergencies of our educational situation. It may be further added that of glowing prophecies of enlarged attendance has not tended to increase their confidence in the wisdom of the change (Salley 1985, 96).

The decision was made after the year 1909-1910 to only admit women who could live off-campus. Friley was informed he would not be retained after a year of service. Health and his advanced age may have been other factors in Friley's short tenure, serving only a year as president. He was 63 when he arrived in Pineville, and died just the year after leaving the presidency (Salley 1985).

Claybrook Cottingham, a member of the faculty since the college's opening, was appointed president in 1910. His tenure began amid a sense of optimism, as the college was poised to build upon its campus life, in addition to its curriculum. A campaign was begun to raise $\$ 100,000.00$ for buildings and equipment (May 1956).

Though the early Cottingham years were successful and exciting, they were not without obstacles, the first of which was a January 3, 1911 fire that destroyed the college's main building, Ware Hall, and the kitchen. The fire, emanating from the building's furnace, was unable to be extinguished because the fire hydrants were frozen and thus there was no water with which to combat the flames (May 1956). Less than five years after beginning its service in a single wooden building, Louisiana College was reduced to its original facility. Cottingham rallied the students to remain at the college and to continue the semester without interruption, and the citizens of Pineville offered more rooms than were needed to house the students. They also established a fund to help students replace their personal items lost in the fire ("A Word to the Friends" 1911).

The loss of Ware Hall was further complicated by the fact it had been built with a debt of $\$ 50,000$ but was only insured for $\$ 20,000$ ("Will Rebuild College" 1911). The future of the college's location was in limbo in the spring of 1911. Some called for the college to be moved to Mount Lebanon, given the campus was already developed (Higgins 1971). Others, including Mayor J. P. Turregano, wanted the college to relocate in Alexandria. E. O. Ware led a group who wanted the college to remain in Pineville, and when more than one-hundred fifty messengers arrived for a special called meeting of the Louisiana Baptist Convention on April 5, the Pineville citizens provided trains to transport them to the campus for a tour and a free lunch. They boasted of the elevation, the acreage, the deep artesian well, proximity to three railroads, and the homes that had been built near the campus for faculty and staff in the early years ("Pineville is Hustling" 1911). After a marathon meeting that concluded after two o'clock in the morning of 
April 6 that included speeches by President Cottingham and E. O. Ware, the Convention voted to keep the college in Pineville by a vote of 129-29 ("College Stays at Pineville" 1911).

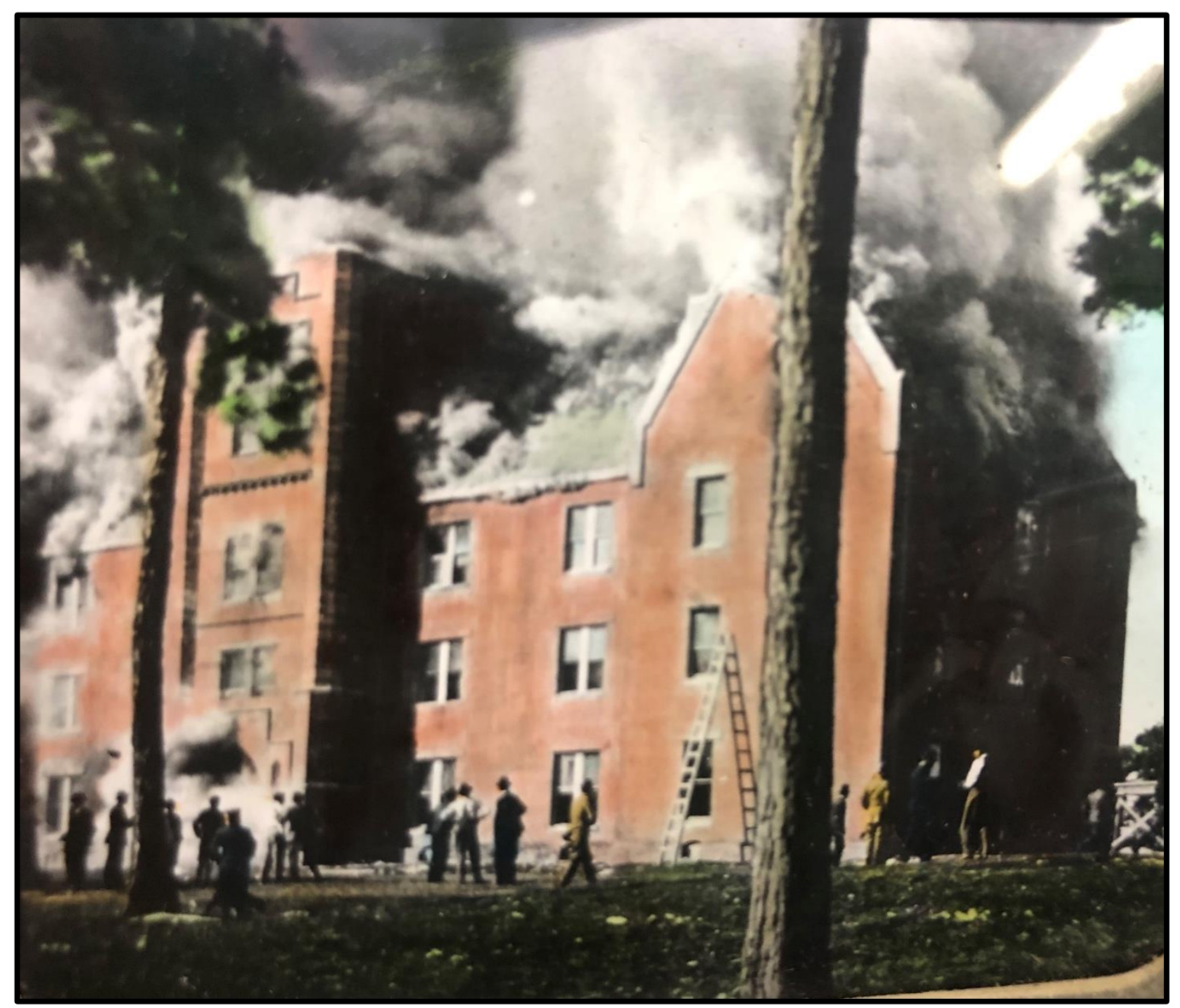

Image 2. "Fire," January 3, 1911. Image courtesy of the Richard W. Norton Library, Archives, Pineville, Louisiana.

President Cottingham proved himself to be an effective advocate for the college during his first year as president while the college recovered from the fire. In his book on early institutional leaders in Louisiana, Rodney Cline described Cottingham this way, "a gifted speaker with an attractive personality...he never missed an opportunity to occupy a church pulpit, or otherwise to address a public assembly," for the purpose of promoting Louisiana College (Cline 1969, 52). In the days following the vote of the Convention to keep the college in Pineville, he offered his own resignation and gave a speech in which he implored the Baptists to truly support the college or give up the effort:

Either they will do in the future as they have done in the past-play at the matter in a half-hearted way, and allow the school to be handicapped in its growth and usefulness 
by lack of funds - not allowed to die, nor yet permitted to have a vigorous life; or they will arise in their strength, show themselves to be larger than their prejudices, and build and equip a school worthy of the strength of Louisiana Baptists; or they will quit (May 1956, 31).

Cottingham's resignation was refused, and he was given some assurances of better future support of the college. He kept up the pressure, asking for more support in 1913 and 1914. In 1916, Edgar Goldbold, who would succeed Cottingham in 1942, was hired as Concurring Secretary for the Education Commission and helped raise $\$ 40,700$ for an additional residence hall in just forty days. Cottingham lobbied the General Education Board of New York for funds in 1919, and in 1920 he began a campaign to raise money for a new administrative building, to be named Alexandria Hall. The college received $\$ 75,000.00$ from the board, but the Convention covered most of the building's cost of construction (May 1956).

\section{Years of Steady Progress}

The catalogs of the 1910 s maintained that the "college was easily accessible from any portion of the State," given the campus' proximity to several railroads and the recent construction of a traffic bridge between Alexandria and Pineville (Catalog of Louisiana College, 1913-1914, 29). The wooded 40-acre campus, flush with native Pines and Oaks and blessed with fresh water, sounded appealing. The inclusion of information that a cemetery and the Louisiana Hospital for the Insane were nearby must have been less effective for recruiting. The men were guaranteed their own bed and their rooms were lighted; the women's dormitory was noted as having all the modern conveniences (Catalog of Louisiana College, 1913-1914).

The period from the fire in 1911 until the mid-1920s was one of profound progress for Louisiana College. For part of it, the college enjoyed the editorial assistance of E. O. Ware who purchased The Baptist Chronicle in 1913 and published it until 1919. He urged support of the college and applauded those who did. With the closure of Louisiana Baptist Female College in 1912, residential women were again admitted. In 1913, a women's basketball team was added. An enrollment of 200 was achieved in 1914. It would peak at 623 in 1926 (May 1956). A swimming pool, paid for in large part by student fees, was opened in 1919 at the end of the pandemic. A gym was opened in 1922 . The endowment surpassed $\$ 300,000$ by 1925 . But these accomplishments were often well short of the original goals Cottingham and the Baptists set for the institution. The "75 Million Dollar Campaign for Southern Baptists" intended to raise more than $\$ 1,000,000$ for Louisiana College; it garnered just over $\$ 400,000$ (May 1956). At times, for example with Alexandria Hall, the Convention had to absorb the debt.

The college's academics enjoyed continual improvement. It received designation as a "standard college" by the State of Louisiana in 1916, and in 1923 became only the third institution in the state to be accredited by Southern Association of Colleges and Schools, joining Louisiana State University and Tulane University. The college regularly added programs to adjust to conditions. When World War I began, for example, military training was incorporated into 
the curriculum and the campus was essentially turned over to the War Department. At the same time, a new major "domestic science," later home economics, was added to grow the female population (Catalog of Louisiana College, 1917-1918). These two strategies resulted in a higher enrollment during the war years despite the loss of most regular male students.

The campus life enjoyed continued growth. In January 1910, Louisiana College, along with Louisiana State Normal College, Centenary College of Louisiana, and the Louisiana Industrial Institute founded the Louisiana Intercollegiate Association. The league sponsored competition in football, basketball, and baseball ("Intercollegiate Association Formed" 1910). The development of the college's athletic program was critical in its overall enrollment growth. Football and baseball teams appeared in 1907, but the 1910-1911 year, by virtue of membership in the Louisiana Intercollegiate Association, marked the true beginning of college athletics for Louisiana College. Coach Simon W. Tudor, who had enjoyed a successful playing career at Georgetown College (KS), led the football program, beginning in 1910 ("Louisiana College Football" 1910). College enrollment doubled between 1909 and 1910, even though women were not recruited as residential students ("Louisiana Football Closes" 1910). Perhaps the fall of 1910 was when the campus began to have a true college spirit. The college colors of burnt orange and navy blue were selected that term by a committee, composed of Professor Bruce Benton's wife and others (Hoffmeyer 1981). In addition to football, a student paper, The Messenger, began circulation. An early edition includes this passage that demonstrates the upstart college's confidence about its athletic prowess, "We are ready to tackle any of the big colleges, for we will never believe that the orange and blue can be beaten until we are shown" ("Athletic Notes" 1911, 34). It became The Wildcat in 1921, and began to resemble a weekly.

This confidence proved to be merited as the 1911 football went undefeated, outscoring its opponents 54-3 ("Louisiana College Ends" 1911). The following year, the team played LSU's second team in Baton Rouge ("Off for Baton Rouge" 1912). And in 1913, the college played The Louisiana Industrial Institute at the Louisiana State Fair, as a part of a triple header, featuring LSU and The University of Arkansas. One-hundred faculty and staff accompanied the football team aboard a train to participate in "College Day" ("Will Go to Shreveport 1913). In just its eighth year, Louisiana College, by way of intercollegiate athletics, was sharing a stage with larger and more venerable institutions.

Athletics enjoyed broad support, with track and tennis added in the 1910s. The catalogs appear to have tried to balance the excitement of athletics with the purpose of a college education. Louisiana College "believes in rational college athletics," and "is proud that its boys have done well in their contests with other colleges (Catalog of Louisiana College, 1917-1918, 31-32). President Cottingham was generally supportive of college athletics, and was influential in the college being accepted into the Southern Intercollegiate Athletic Association in 1923. He served two terms as vice president for the organization. Cottingham often reported of the college's athletic success in his articles in The Baptist Chronicle, remarking "No matter what is on, you may look out for Louisiana College. She intends to be ahead (Higgins, 1971, 117). 
Additional student organizations appeared, including those exclusively for women. The 1914 yearbook, The Pine Knot, listed a Suffragette Club and a Chafing Dish Club. This is indicative of women who preferred traditional roles, as well as those who were challenging norms and demanding equality. Plays were regularly produced by the Expression Club in the mid-1910s. Intercollegiate Debate and the Glee Club appeared by 1917. The athletic teams enjoyed regular coverage, as did the two major literary societies, the Athenians and the Cadmians. Several recurring columns recorded snippets of the campus goings on. "Pine Needles" reported friendly insults, while "Personal and Social" provided remarkably detailed information about students' personal lives, where they went, what they did, and with whom. "Religious Activities" summarized the spiritual activities on and off campus ("The Wildcat" 1923).

\section{Cottingham's Idea of the Christian College}

Claybrook Cottingham was an ardent believer in the small denominational college. In a pamphlet the college produced in 1912, he outlined much of his philosophy. He respected the state institutions which were fast developing during his tenure at Louisiana College as essential, "The vastness of the work gives us all a place and a mission" (Cottingham 1912). He viewed the Christian colleges as critical in maintaining the nation's character, "I do hold, however, that the moral conservation of the race can be accomplished at its best only in the Christian school."

The periodical, mailed to the churches around the state, included several warnings about the secular schools and their dangers to Christian young people. Cottingham cited his involvement with a committee of college professors from around the state, noting that the majority of them drank beer at a shared meal and were thus a potential bad influence for young men under their instruction (Cottingham 1912). He told the story he heard of one college student from New Orleans who had been considering the Christian faith but rejected it because his favorite professor was an atheist. His most extreme warning was that an unidentified state school's administrator reported that twenty-five percent of his student body was suffering from "genito-illnesses." Cottingham, a former professor of Greek and philosophy, offered, "Of course, it is known to you that when a man has fallen a victim to such an ill he never again be fully efficient as a citizen or safe as parent."

While Cottingham philosophically viewed the state institutions as morally lax and detrimental for society, he practically feared them as formidable competitors for students and funds. In a radio speech, he lamented the tendency of students to attend state schools over the liberal arts colleges in the early twentieth century. Similarly, he critiqued American culture's infatuation with bigness and how benefactors were directing their funds toward the entities that could get them the most attention (Cottingham Unknown).

\section{Integral Personnel}

It is important to mention some of the dedicated faculty and staff who were recruited to the college during the early years, many of whom remained through the Great Depression. Their remaining at the college, despite the challenges, ensured continuity. Hal Monroe Weathersby a 
graduate of Mississippi College, arrived in 1911, to teach Greek and history. He assumed the role of dean of the college in 1914, a task more akin to provost or vice president for academic affairs today, and remained until his retirement in 1956. Dean Weathersby's tenure touched that of three presidents, and he served as acting president between President Cottingham and President Godbold (Hoffmeyer 1981).

Coach Henry Walden joined the college in 1921, later serving as athletic director until his retirement in 1961. Professor William Strother came to the college in 1914, and served, mostly as a professor of political science, until his retirement in 1949. O. B. Owens, eventually an M.D., taught biology from 1921-1945. Edgar Goldbold, who of course succeeded Cottingham as president, served as professor of biology and as a secretary for the commission (Hoffmeyer 1981.) This odd arrangement probably would be frowned upon today for governance reasons, as Godbold was a subordinate to Cottingham as a biology professor and served the body which employed Cottingham in the other. Godbold's wife held many positions, including that of dean of women.

In addition to talented students, faculty, and staff, Louisiana College was served by generous and long-time Education Commission members who became its first trustees. E. O. Ware cannot be credited enough for his support of Louisiana College during its first two decades of existence. From proposing the resolution calling for a new college in 1893, serving as financial agent during the first three sessions, as president in 1909-1910, and advocating for the college remaining in Pineville in 1911, he was always "for Louisiana College." W. C. Beall, a "quiet Lumberman" from Pineville served on the Education Commission from 1906-1920 and as a trustee from 1921-1940 (Hoffmeyer 1981). He gave $\$ 10,000$ in a single gift, made a loan he never collected for another $\$ 10,000$, and secretly paid for half the cost of Godbold Hall's construction (Greene 1973). J.A. Edward of Ruston served from 1906-1937 on the commission and board. J.A. White of Alexandria served the longest of any, from 1906-1945 (Hoffmeyer 1981). They, and others, often signed personal loans on behalf of the college.

\section{Why Louisiana College Survived Its First Twenty Years}

Louisiana College survived its first two decades because it found favor in several factors its "spiritual predecessors" did not. To begin with, Louisiana College was not disrupted by the Civil War during its first decade. Beyond that, its home in Pineville was located near the geographic center of the state and in an area that was near several railroads, thus ensuring students beyond the immediate area could reach the campus. With the City of Pineville, the college found a generous offer of land and continued support when the 1911 fire devastated the single brick structure. The City of Alexandria also proved to be a great resource, as the funds its citizens raised to initially lure the institution to the other side of the river were still given to the college.

The college's early faculty, staff, students, trustees, and supporters proved more than up to the task of sustaining an institution. The college was blessed with faculty who were both qualified and patient with the various setbacks the college experienced, especially between 
1907 and 1912. Claybrook Cottingham's appointment as president was pivotal, as he provided three decades of stewardship. The students who took a chance on an upstart college brought to the campus a spirit befitting an older institution.

\section{REFERENCES}

"Athletic Notes." 1911. The Messenger. January, 1911.

Brister, Elaine. 1968. Once Upon a River: A History of Pineville, Louisiana. Baton Rouge: Claitor's Publishing Division.

Catalog of Louisiana College, Session 1908-1909 with Announcements for Session 1908-1909. Catalog of Louisiana College, Session 1908-1909 with Announcements for Session 1909-1910. Catalog of Louisiana College, Session 1908-1909 with Announcements for Session 1910-1911. Catalog of Louisiana College, Session 1908-1909 with Announcements for Session 1913-1914. Catalog of Louisiana College, Session 1908-1909 with Announcements for Session 1917-1918. Cline, Rodney. 1969. Pioneer Leaders and Early Institutions in Louisiana Education. Baton Rouge: Claitor's Publishing Division.

“College Stays at Pineville." 1911. Alexandria Daily Town Talk. April 6, 1911.

Cottingham, Claybrook. 1911. "A Word to the Friends of Louisiana College. Letter to the Editor, The Alexandria Daily Town Talk. January 7, 1911.

Cottingham, Claybrook. Date Unknown. Speech on Radio Station KWKH, Shreveport, Louisiana. Cottingham, Claybrook. Letter to Penrose St. Amant, November 19, 1947.

Cottingham, Claybrook. 1912. Pamphlet.

"Commission of State Baptist College Met Here Last Night." 1906. Alexandria Daily Town Talk. March 23, 1906.

Greene, Glenn. 1973. House Upon the Rock: About Southern Baptists in Louisiana. Alexandria: Executive Board of the Louisiana Baptist Convention.

“Ground Broken for Baptist College." 1906. Alexandria Daily Town Talk. June 11, 1906.

Higgins, George. 1971. "The Louisiana Baptist Convention and Christian Education: 1893-1956. EdD diss., Oklahoma State University.

Hoffmeyer. Oscar, Jr., 1981. Louisiana College 75 Years: A Pictorial History. Pineville: Louisiana College.

"Intercollegiate Association Formed to Foster Athletic and Intercollegiate Contests." 1910. Alexandria Daily Town Talk. January 15, 1910.

"Louisiana College Ends Football Season-Basketball Next." 1911. Alexandria Daily Town Talk. November 21, 1911.

“Louisiana College Football is Getting Down to Hard Practice Now." 1910. Alexandria Daily Town Talk. October 1, 1910.

“Louisiana Baptist College Opened for Session." 1906. Times-Democrat. October 3, 1906. “Louisiana Football Closes Season.” 1910. Alexandria Daily Town Talk. November 16, 1910. 
May, Lynn. 1956. “Claybrook Cottingham: A Study of His Life and Work. ThD Diss., New Orleans Baptist Theological Seminary.

“Notice, Contractors." 1906. Alexandria Daily Town Talk. May 5, 1906.

"Off for Baton Rouge: Louisiana College Boys to Play L.S.U." 1912. Alexandria Daily Town Talk. November 16, 2012.

“Pineville is Hustling." 1911. Alexandria Daily Town Talk. April 4, 1911.

Ringenberg, William. 2006. The Christian College. 2nd ed. Grand Rapid: Baker Academic.

Salley, Landrum. 1985. “An Historical Survey of the Curriculum of Louisiana College, 1906-1983. EdD diss., Vanderbilt University.

"Statement of Louisiana College." 1910.

Thelin, John. 2019. A History of American Higher Education. 3 ed. Baltimore: John Hopkins University Press.

“The Louisiana College." 1906. Alexandria Daily Town Talk. August 4, 1906.

"The State Baptist College to be Located Back of Pineville." 1906. Alexandria Daily Town Talk. January 20, 1906.

The Wildcat. December 19, 1923, 1.

"Will Go to Shreveport." 1913. Alexandria Daily Town Talk. November 7, 1913.

“Will Rebuild College." 1911. Alexandria Daily Town Talk. January 7, 1911. 